\title{
The role of bile salts in diarrhoea of patients with ulcerative colitis
}

\author{
T. A. MIETTINEN \\ From the Third Department of Medicine, University of Helsinki, Helsinki 29, Finland
}

SUMMARY Faecal bile salt elimination, which was determined in patients with ulcerative colitis, was mostly within normal limits, suggesting that in this disease water and electrolyte diarrhoea was hardly contributed to by excessive amounts of bile salts in the large bowel. In a therapeutic trial cholestyramine had no beneficial effect on the general condition, diarrhoea, or faecal composition, findings which further strengthen the view that bile salts play no role in the diarrhoea of ulcerative colitis, provided that the disease is limited to the large bowel. Faecal elimination of cholesterol as bile salts and neutral steroids tended initially to be higher than normal, but increased less than in controls during treatment with cholestyramine, particularly in the heavier patients. Serum cholesterol was low in the patients with ulcerative colitis and decreased by cholestyramine less $(27 \%)$ than in controls $(39 \%)$.

Recent studies have indicated that in patients with ileal dysfunction bile acids entering the colon in augmented amounts can aggravate the diarrhoea (Hofmann and Poley, 1969) by enhancing colonic motility (Meyer and McEwan, 1948; Bergmann, 1952) and by stimulating electrolyte and water secretion into the colon and inhibiting their absorption from the large bowel (Forth, Rummel, and Glasner, 1966; Mekhjian, Phillips, and Hofmann, 1968; Phillips, Mekhjian, and Hofmann, 1970). Binding of bile acids with cholestyramine (Rowe, 1967; Hofmann and Poley, 1969; Sickinger, 1969; Bahls, 1970; Miettinen and Lempinen, 1970) or lignin (Eastwood and Girdwood, 1968) has been reported to alleviate diarrhoea in subjects with ileal resection and ileal bypass. Since bile salts are normally absorbed to a certain extent from the colon in man (Mekhjian et al, 1968; Samuel, Saypol, Meilman, Mosbach, and Chafizadeh, 1968), damage to the colonic mucosa in ulcerative colitis may inhibit this reabsorption. Bile acids may thus contribute to the diarrhoea and, by their possible toxic effect on intestinal mucosa (Shiner, 1969), worsen damage to the mucosa of the colon. Therefore, the role of bile acids in diarrhoea was evaluated in the present study by determining the faecal elimination of bile salts in patients with colonic lesions of varying severity and exploring the effect of cholestyramine treatment on clinical condition, faecal frequency, and faecal composition.

Received for publication 25 May 1971.

\section{Material and Methods}

The subjects studied were six controls (cases 1-6) from among the laboratory personnel and five patients (cases 7-11) with ulcerative colitis. Clinical and laboratory data are presented in Table $I$. $X$-ray and sigmoidoscopic examinations indicated that in two of the patients (cases 7 and 8) severe changes were present from the rectum up to the transverse colon, while the caecum and ascending colon appeared normal. In case 7 , with the most severe $x$-ray findings, the patient later underwent proctocolectomy. Operation showed that the ascending colon was affected but the terminal ileum was intact. In cases 9 and 10 slight $x$-ray and sigmoidoscopic changes were observed, while in case 11 there were only sigmoidoscopic alterations, the radiograph being normal.

All the patients and controls were placed on a low-cholesterol solid food diet (70-125 mg/day), the fat content being $80 \mathrm{~g} / 2,400 \mathrm{kcal}$. Unabsorbable $\mathrm{Cr}_{2} \mathrm{O}_{3}$ and sitosterol, $600 \mathrm{mg}$ each divided into three daily doses, were given so that the respective corrections for faecal flow and degradation of cholesterol during intestinal transit (Grundy, Ahrens, and Salen, 1968) could be made. Gas-liquid chromatographic (GLC) analysis of the sitosterol showed that it contained $85 \%$ of $\beta$-sitosterol and $15 \%$ of other plant sterols. Measurement of dietary sterols indicated that the average total intake of $\beta$ sitosterol was $624 \mathrm{mg} /$ day. Two stool collections, 
each over two days, were made after five days on the diet, $\mathrm{Cr}_{2} \mathrm{O}_{3}$, and $\beta$-sitosterol. Thereafter cholestyramine (Cuemid), $32 \mathrm{~g}$ a day, was started for eight to 10 days and stool collections were continued. Serum cholesterol was determined (Pearson, Stern, and McGawack, 1953) before and at the end of the cholestyramine period.

Faecal bile acids and neutral steroids and dietary sterols were analysed by the gas liquid chromatography methods (Grundy, Ahrens, and Miettinen, 1965; Miettinen, Ahrens, and Grundy, 1965), faecal fat according to van de Kamer, ten Bokkel Huinink, and Weyers (1949), and chromium as presented by the methods of Bolin, King, and Klosterman (1952). Since no loss of $\beta$-sitosterol was found during intestinal transit (recovery of dietary plus administered $\beta$-sitosterol in the faeces was complete in every case), the values are expressed in terms of $\mathrm{Cr}_{2} \mathrm{O}_{3}$. For this purpose the amount of steroid or fat per mg of $\mathrm{Cr}_{2} \mathrm{O}_{3}$ in the faeces was multiplied by 600 . Sterol balance, which in the steady state is equal to cholesterol synthesis, was given by the difference between dietary cholesterol and faecal steroids (sum of bile acids and neutral steroids of cholesterol origin).

\section{Results}

Data of Table I show that none of the patients had any gross steatorrhoea, though frequency of bowel movements and faecal mass (primarily due to excessive water) was markedly augmented. Faecal bile acid elimination was mostly normal (Table II), however, and bore no significant relationship to the faecal mass or water, so that the watery diarrhoea was not attributable to excessive amounts of bile salts. In patient 7 , who later underwent colectomy, the values were slightly elevated, particularly when expressed per kilogram of body weight. The sterol balance, which showed a positive correlation with body weight ( $r=0.89$ for patients $; 0.66$ for controls), tended to be higher in the patients than in the controls, especially when expressed per kilogram of body weight. Serum cholesterol was low, suggesting that the slightly increased elimination of cholesterol into the faeces was not sufficiently balanced by enhanced cholesterol synthesis (Table II).

Cholestyramine clearly impaired the patient's condition in case 8 both clinically and according to faecal water and fat, while in the four remaining cases the status remained essentially unchanged. In cases 8-11 the cholestyramine treatment was followed by administration of Salazopyrin and rectal prednisone enemas, and immediate improvement was recorded, all the symptoms disappearing within 10 days. Thus, cholestyramine has no favourable effect on ulcerative colitis limited to the colon and not extended to the terminal ileum.

Neither the average faecal mass, water, dry weight, nor fat were affected by cholestyramine in the five patients, while in the controls faecal mass was augmented, due to excessive water output. Bile acid excretion and sterol balance values were markedly increased by cholestyramine in every patient but, in contrast to controls, showed an inverse relation to the body weight (Fig. 1). Thus, the average increment of faecal bile acid putput was significantly lower in the patients than in the controls. The fall in serum cholesterol was correspondingly higher in the latter $(39 \%)$ than in the former $(27 \%)$.

\begin{tabular}{|c|c|c|c|c|c|c|c|c|c|c|c|c|c|c|}
\hline \multirow{2}{*}{$\begin{array}{l}\text { Case } \\
\text { No. }\end{array}$} & \multirow[t]{2}{*}{ Age } & \multirow[t]{2}{*}{$\operatorname{Sex}$} & \multirow{2}{*}{$\begin{array}{l}\text { Weight } \\
(k g)\end{array}$} & \multirow{2}{*}{$\begin{array}{l}\text { Relative } \\
\text { Weight }\end{array}$} & \multirow{2}{*}{\multicolumn{2}{|c|}{$\begin{array}{l}\text { No. of } \\
\text { Daily Stools }\end{array}$}} & \multicolumn{8}{|c|}{ Faecal Components (g/day) } \\
\hline & & & & & & & \multicolumn{2}{|c|}{ Total Weight } & \multicolumn{2}{|l|}{ Water } & \multicolumn{2}{|c|}{ Dry Matter } & \multicolumn{2}{|l|}{ Fat } \\
\hline $\begin{array}{l}\text { Control subjec } \\
1-6 \\
\text { Mean } \pm \text { SE } \\
\text { Change }^{2}\end{array}$ & $\begin{array}{l}29 \\
\pm 2\end{array}$ & $F \& \mathbf{M}$ & $\begin{array}{l}63 \\
\pm 5 \\
-\end{array}$ & $\begin{array}{r}0.97 \\
\pm 0.02 \\
-\end{array}$ & $\begin{array}{l}- \\
-\end{array}$ & - & $\begin{array}{r}120 \\
\pm 24 \\
+107\end{array}$ & $\begin{array}{l}228 \\
\pm 16 \\
\pm 19^{3}\end{array}$ & $\begin{array}{r}92 \\
\pm 22 \\
+64\end{array}$ & $\begin{array}{l}155 \\
\pm 14 \\
\pm 17^{3}\end{array}$ & $\begin{array}{r}29 \\
\pm 3 \\
+43\end{array}$ & $\begin{array}{r}73 \\
\pm 4 \\
\pm 2^{2}\end{array}$ & $\begin{array}{r}1.9 \\
\pm 0.3 \\
+1.7\end{array}$ & $\begin{array}{r}2.4 \\
\pm 0.6 \\
\pm 0.9\end{array}$ \\
\hline $\begin{array}{l}\text { Patients with } \\
7 \\
8 \\
9 \\
10 \\
11 \\
7-11 \\
\text { Mean } \pm \text { SE } \\
\text { Change? }\end{array}$ & $\begin{array}{c}\text { tive c } \\
17 \\
26 \\
22 \\
52 \\
25 \\
28 \\
\pm 6 \\
-\end{array}$ & $\begin{array}{l}\text { is } \\
\mathbf{M} \\
\mathbf{F} \\
\mathbf{F} \\
\mathbf{M} \\
\mathbf{M}\end{array}$ & $\begin{array}{r}48 \\
54 \\
62 \\
72 \\
86 \\
64 \\
\pm 7 \\
-\end{array}$ & $\begin{array}{r}0.72 \\
0.93 \\
0.94 \\
1.12 \\
1.19 \\
0.98 \\
\pm 0.08 \\
-\end{array}$ & $\begin{array}{l}4-6 \\
2-6 \\
3-5 \\
3-4 \\
3-6 \\
-\end{array}$ & $\begin{array}{l}2-4 \\
4-11 \\
3-4 \\
2-4 \\
4-5 \\
-\end{array}$ & $\begin{array}{r}420 \\
225 \\
397 \\
251 \\
778 \\
414 \\
\pm 994 \\
+97\end{array}$ & $\begin{array}{c}642 \\
549 \\
485 \\
216 \\
663 \\
511 \\
\pm 80^{4} \\
\pm 80\end{array}$ & $\begin{array}{c}364 \\
182 \\
346 \\
208 \\
703 \\
361 \\
+934 \\
+68\end{array}$ & $\begin{array}{l}558 \\
456 \\
412 \\
160 \\
561 \\
429 \\
\pm 734 \\
\pm 76\end{array}$ & $\begin{array}{r}56 \\
43 \\
51 \\
43 \\
75 \\
54 \\
\pm 6^{8} \\
+22\end{array}$ & $\begin{array}{l}84 \\
93 \\
73 \\
56 \\
72 \\
76 \\
\pm 6 \\
\pm 9\end{array}$ & $\begin{array}{r}3 \cdot 2 \\
4 \cdot 7 \\
4.9 \\
5 \cdot 0 \\
8 \cdot 0 \\
5 \cdot 2 \\
+0 \cdot 8 \\
+2 \cdot 5\end{array}$ & $\begin{array}{r}3.7 \\
13.6 \\
7.4 \\
6.1 \\
7.8 \\
7.7 \\
\pm 1.6^{3} \\
\pm 1.6\end{array}$ \\
\hline
\end{tabular}

Table I Clinical and laboratory data of control subjects and patients with ulcerative colitis treated with cholestyramine

The amount of unabsorbable resin $(32 \mathrm{~g} /$ day $)$ has not been subtracted from faecal weight or dry matter. $B=$ before and $D=d$ uring cholestyramine treatment. ${ }^{2}$ Mean difference $\left( \pm\right.$ SE) from pretreatment values. Statistically significant $(P<0.05)$ changes are indicated by ${ }^{3}$ and differences from the controls by $\bullet$. 


\begin{tabular}{|c|c|c|c|c|c|c|}
\hline \multirow{2}{*}{$\begin{array}{l}\text { Case } \\
\text { No. }\end{array}$} & \multicolumn{3}{|c|}{ Faecal Steroids (mg/day) } & \multicolumn{2}{|c|}{ Sterol Balance } & \multirow{2}{*}{$\begin{array}{l}\text { Serum } \\
\text { Cholesterol } \\
\left(\mathrm{mg} / 100 \mathrm{~m}^{\eta}\right)\end{array}$} \\
\hline & $\begin{array}{l}\text { Bile } \\
\text { Acids }\end{array}$ & $\begin{array}{l}\text { Neutral } \\
\text { Steroids }\end{array}$ & $\begin{array}{l}\text { Total } \\
\text { Steroids }\end{array}$ & $m g / d a y$ & $m g / k g / d a y$ & \\
\hline $\begin{array}{l}\text { Control subjec } \\
1-6 \\
\text { Mean } \pm \text { SE } \\
\text { Change }^{1}\end{array}$ & $\begin{array}{r}232 \\
\pm 45 \\
+1,776 \\
\pm 208^{2}\end{array}$ & $\begin{array}{r}631 \\
+108 \\
+42 \\
\pm 57\end{array}$ & $\begin{array}{r}863 \\
\pm 117 \\
+1,818 \\
\pm 255^{2}\end{array}$ & $\begin{array}{r}-770 \\
\pm 110 \\
-1,818 \\
\pm 255^{2}\end{array}$ & $\begin{array}{c}-12.3 \\
\pm 1.4 \\
-28.9 \\
\pm 2.4^{2}\end{array}$ & $\begin{array}{l}209 \\
\pm 11 \\
-81 \\
\pm 10^{2}\end{array}$ \\
\hline $\begin{array}{l}\text { Patients with } \\
7 \\
8 \\
9 \\
10 \\
11 \\
7-11 \\
\text { Mean } \pm \text { SE } \\
\text { Change }\end{array}$ & $\begin{array}{c}\text { olitis } \\
463 \\
159 \\
288 \\
238 \\
353 \\
300 \\
\pm 52 \\
+1,055 \\
\pm 160^{2,8}\end{array}$ & $\begin{array}{l}427 \\
936 \\
830 \\
927 \\
950 \\
814 \\
\pm 99 \\
+95 \\
\pm 59\end{array}$ & $\begin{array}{r}890 \\
1,095 \\
1,118 \\
1,165 \\
1,303 \\
1,114 \\
\pm 67 \\
+1,150 \\
\pm 209^{2}\end{array}$ & $\begin{array}{r}-796 \\
-1,012 \\
-1,028 \\
-1,071 \\
-1,178 \\
-1,107 \\
\pm 62 \\
-1,150 \\
\pm 209^{2}\end{array}$ & $\begin{array}{c}-16.6 \\
-18.7 \\
-16.8 \\
-14.9 \\
-13.7 \\
-16.1 \\
\pm 0.8^{3} \\
-19.9 \\
\pm 5.2^{2}\end{array}$ & $\begin{array}{c}115 \\
184 \\
153 \\
150 \\
180 \\
157 \\
\pm 15^{2} \\
-42 \\
\pm 8^{2}, 3\end{array}$ \\
\hline
\end{tabular}

Table II Faecal steroids, sterol balance, and serum cholesterol in control subjects and patients with ulcerative colitis treated with cholestyramine

${ }^{1}$ Mean change $\left( \pm\right.$ SE) caused by cholest yramine. Statistically significant $(P<0.05)$ changes indicated by ${ }^{2}$ and differences from the controls by

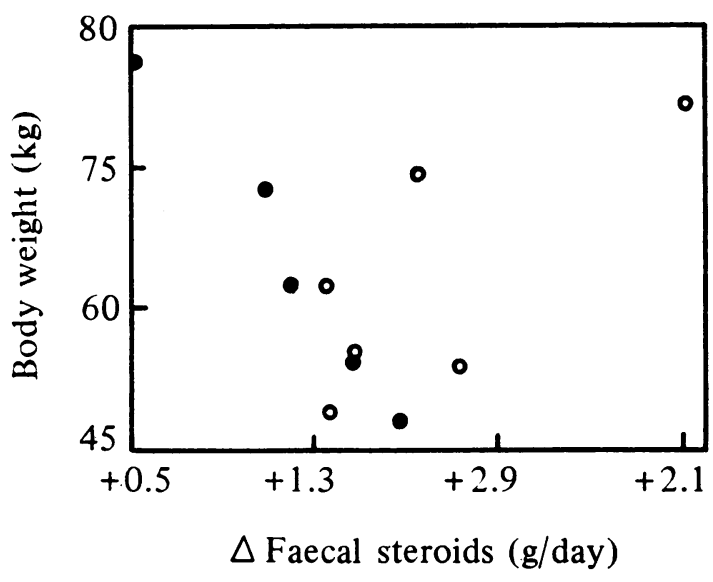

Fig. 1 Correlation of body weight with faecal steroid increment in control subjects $(O)$ and in patients with ulcerative colitis $(\mathbf{O})$.

\section{Discussion}

Diarrhoea of ulcerative colitis depends on enhanced exudation of electrolytes and water through the damaged mucosa and impaired absorption of sodium and water from the ileal contents of the large bowel (Duthie, Watts, deDombal, and Goligher, 1964; Harris and Shields, 1970). If bile salt absorption, known to occur in the colon to some extent (Mekhjian et al, 1968; Samuel et al, 1968), were similarly diminished, then cholerrhoeic diarrhoea might contribute to the excessive water and electrolyte loss found in this disease. Bile salts, particularly free dihydroxy bile acids, at high enough concentrations not only inhibit electrolyte and water absorption from the large bowel but also stimulate the secretion of sodium and water into the intestine (Forth et al, 1966; Mekhjian et al, 1968; Phillips et al, 1970). These mechanisms appear to contribute to the diarrhoea in ileal dysfunction so that binding of bile acids with cholestyramine decreases faecal weight, water content, and frequency (Rowe, 1967; Hofman and Poley, 1969; Sickinger, 1969; Bahls, 1970; Miettinen and Lempinen, 1970). The results of the present study showed that in patients with ulcerative colitis, limited to the large bowel, there is no excessive faecal loss of bile salts, so that cholerrhoeic diarrhoea does not exist.

The absence of large amounts of bile salts in the colon obviously explains the failure of cholestyramine to alleviate the diarrhoea by binding bile acids. This also indicates that bile salts, known to injure intestinal cells in vivo at high concentrations (Shiner, 1969), have hardly any additional damaging effect on the diseased colonic mucosa in ulcerative colitis. But in the cases in which the inflammatory and ulcerative processes extend to the terminal ileum ('back-wash' ileitis) ileal dysfunction may develop. Under these conditions large amounts of bile salts may escape into the colon, contributing to the diarrhoea and perhaps worsening the mucosal ulceration through their cytotoxicity. In regional enteritis enhanced faecal bile salt excretion has actually been found in many but not all cases (Stanley and Nemchausky, 1967; Meihoff and Kern, 1968; Fiasse, Eyssen, Dive, Harvengt, Kestens, and Nagant de Deuxchaisnes, 1970).

The reason for the small increase in bile salt output during cholestyramine treatment in the 
colitis patients may be due to effective reabsorption of bile salts or limited hepatic capacity to enhance bile salt synthesis, particularly in the two slightly obese subjects. The limited synthesis may have been caused by anorexia and weight loss, which are almost invariably part of the clinical picture of active ulcerative colitis, or by associated liver disorder, which is frequently found in this disease (cf. Wright, 1970). No laboratory signs of liver damage were seen; liver biopsies were not performed. Pericholangitis and fatty change are often found in liver biopsies in ulcerative colitis, even when the liver function tests are normal (cf. Wright, 1970). All the patients had lost weight before admission to hospital and tended to do so even during their stay in hospital, despite an apparently sufficient caloric intake. Faecal bile acid excretion and bile salt synthesis are actually reduced in man during caloric restriction not only under basal conditions but apparently also during cholestyramine treatment (Miettinen, 1968). However, the fact that no marked steatorrhoea developed during cholestyramine treatment in the patients with ulcerative colitis suggests that the intestinal bile salt concentration was maintained high enough for fat absorption by enhanced hepatic synthesis of bile salts.

Skilful technical and secretarial assistance given by Mrs E. Gustafsson, Mrs P. Hoffström, and Mrs U Kaski is acknowledged. The study has been performed under a contract with the Association of Finnish Life Assurance Companies.

\section{References}

Bahls, G. (1970). Chologene Diarrhoen nach Ileumresektion und ihre Behandlung mit Cholestyramin. Z. Gastroent., 8, 41-43.

Bergmann, M. (1952). Ueber die peristaltische Wirksamkeit der Gallensäuren und ihre klinische Anwendung. Wien klin. Wschr., 64, 704-707.

Bolin, D. W., King, R. P., and Klosterman, E. W. (1952). A simplified method for the determination of chromic oxide $\left(\mathrm{Cr}_{2} \mathrm{O}_{3}\right)$ when used as an index substance. Science, 116, 634-635.

Duthie, H. L., Watts, J. M., deDombal, F. T., and Goligher, J. C. (1964). Serum electrolytes and colonic transfer of water and electrolytes in chronic ulcerative colitis. Gastroenterology, 47, 525-530.

Eastwood, M. A., and Girdwood, R. H. (1968). Lignin: a bile-salt sequestrating agent. Lancet, $2,1170-1172$.

Fiasse, R., Eyssen, R., Dive, C., Harvengt, C., Kestens, P. J., and Nagant de Deuxchaisnes, C. (Copenhagen 1970). Metabolism of bile acids, lipids and calcium in Crohn's disease with and without resection. In 4th World Congress of Gastroenterology, Copenhagen, 1970, (Abstracts), p. 354.

Forth, W., Rummel, W., and Glasner, H. (1966). Zur resorptionshemmenden Wirkung von Gallensăuren. Naunyn-Schmiedeberg's Arch. exp. Path. Pharmak., 254, 364-380.

Grundy, S. M., Ahrens, E. H. Jr., and Miettinen, T. A. (1965). Quantitative isolation and gas-liquid chromatographic analysis of total fecal bile acids. J. Lipid Res., 6, 397-410.

Grundy, S. M., Ahrens, E. H. Jr., and Salen, G. (1968). Dietary $\beta$ sitosterol as an internal standard to correct for cholesterol losses in sterol balance studies. J. Lipid Res., 9, 374-387.

Harris, J., and Shields, R. (1970). Absorption and secretion of water and electrolytes by the intact human colon in diffuse untreated proctocolitis. Gut, 11, 27-33.

Hofmann, A. F., and Poley, J. R. (1969). Cholestyramine treatment of diarrhea associated with ileal resection. New Engl.J. Med., 281, 397-402.

van de Kamer, J. H., ten Bokkel Huinink, H., and Weyers, H. A. (1949). Rapid method for the determination of fat in feces. J. biol. Chem., 177, 347-355.

Meihoff, W. E., and Kern, F. Jr. (1968). Bile salt malabsorption in regional ileitis, ileal resection, and mannitol-induced diarrhea. J. clin. Invest., 47, 261-267.

Mekhjian, H. S., Phillips, S. F., and Hofmann, A. F. (1968). Conjugated bile salts block water and electrolyte transport by the human colon. Gastroenterology, 54, 1256.

Meyer, A. E., and McEwen, J. P. (1948). Bile acids and their choline salts applied to the inner surface of the isolated colon and ileum of the guinea pig. Amer. J. Physiol., 153, 386-392.

Miettinen, T. A. (1968). Fecal steroid excretion during weight reduction in obese patients with hyperlipidemia. Clin. chim. Acta, 19, 341-344.

Miettinen, T. A., and Lempinen, M. (1970). Ileal by-pass operation in familial hypercholesterolemia. (Abstr.) Scand. J. clin. Lab. Invest., 25, Suppl. 113, 55.

Miettinen, T. A., Ahrens, E. H. Jr., and Grundy, S. M. (1965). Quantitative isolation and gas-liquid chromatographic analysis of total dietary and fecal neutral steroids. J. Lipid Res., 6, 411424.

Pearson, S., Stern. S., and McGawack, T. H. (1953). A rapid, accurate method for the determination of total cholesterol in serum. Analyt. Chem., 25, 813-814.

Phillips, S. F., Mekhjian, H. S., and Hofmann, A. F. (Copenhagen 1970). Effect of free and conjugated bile acids on electrolyte and water absorption by the human colon. In 4th World Congress of Gastroenterology Copenhagen, 1970, (Abstracts), pp. 563-564.

Rowe, G. G. (1967). Control of tenesmus and diarrhea by cholestyramine administration. Gastroenterology, 53, 1006.

Samuel, P., Saypol, G. M., Meilman, E., Mosbach, E. H., and Chafizadeh, M. (1968). Absorption of bile acids from the large bowel in man. J. clin. Invest., 47, 2070-2078.

Shiner, M. (1969). Effect of bile acids on the small intestinal mucosa in man and rats: a light and electron microscope study. In Bile Salt Metabolism, edited by L. Schiff, J. B. Carey, Jr. and J. M. Dietschy, pp. 41-55. Thomas, Springfield, Illiois.

Sickinger, K. (1969) Die Behandlung der chologenen Diarrhoe und Steatorrhoe des enteralen Gallensäureverlustsyndroms mit Cholestyramin und mittelkettigen Triglyceriden. Dtsch. med. Wschr., 94, 1151-1157.

Stanley, M. M., and Nemchausky, B. (1967). Fecal C'4-bile acid excretion in normal subjects and patients with steroid-wasting syndromes secondary to ileal dysfunction. J. Lab. clin. Med., 70, 627-639.

Wright, R. (1970). Ulcerative colitis. Gastroenterology, 58, 875-897. 